\title{
PERILAKU GENERASI Z TERHADAP PENGGUNAAN MEDIA SOSIAL TIKTOK: TikTok Sebagai Media Edukasi dan Aktivisme
}

\author{
Fadhlizha Izzati Rinanda Firamadhina ${ }^{1}$, Hetty Krisnani ${ }^{2}$ \\ 1,2Program Studi Ilmu Kesejahteraan Sosial Universitas Padjadjaran \\ 1'fadhlizha19001@mail.unpad.ac.id, 2hettykrisnani@yahoo.com
}

\begin{abstract}
Social media is widely a common thing for everyday lives now, Even some people cannot live without it. One of the most downloaded applications in 2020 now is TikTok and they change the game in social media with its 15-60 duration videos. No wonder the impact it has on multiple sectors in the world. But can TikTok operate in the education sector? In this article, the writer will analyze Generation Z's behavior towards TikTok used as educational media and activism. The intervention methods used in this article are with literature review. Results found that TikTok can be used as a form of informal education and digital activism. Informal education, it is found that a model of learning and policy is needed to have its effect on activities. To conclude, social media usage in educational sectors is indeed beneficial, but it needs more further research and models for its applications in its activities.
\end{abstract}

Keywords: Social Media, TikTok, Generasi Z

Media sosial secara luas merupakan hal yang lumrah dalam kehidupan sehari-hari saat ini, bahkan sebagian orang tidak dapat hidup tanpanya. Salah satu aplikasi yang paling banyak diunduh di tahun 2020 sekarang adalah TikTok dan mereka mengubah permainan di media sosial dengan video berdurasi $15-60$. Tidak heran dampaknya terhadap banyak sektor di dunia. Tetapi, bisakah TikTok beroperasi di sektor pendidikan? Pada artikel kali ini penulis akan menganalisis perilaku Generasi Z terhadap TikTok yang digunakan sebagai media pendidikan dan aktivisme. Metode intervensi yang digunakan dalam artikel ini adalah dengan studi pustaka. Hasil penelitian menemukan bahwa TikTok dapat digunakan sebagai bentuk pendidikan informal dan aktivisme digital. Dalam pendidikan informal ditemukan model pembelajaran dan kebijakan yang dapat berpengaruh pada kegiatan. Kesimpulannya, penggunaan media sosial di bidang pendidikan memang bermanfaat, namun perlu lebih banyak penelitian dan model lebih lanjut untuk aplikasinya dalam kegiatannya.

Kata Kunci: Media Sosial, TikTok, Generasi Z

\section{PENDAHULUAN}

Populasi dunia yang terus berkembang menciptakan beberapa generasi. Mulai dari Generasi Baby Boomers (1946-1960) hingga generasi yang memiliki peran vital saat ini yakni Generasi Z atau Gen Z (1995-2010). Generasi Z merupakan generasi pertama yang sejak dini sudah terpapar oleh teknologi. Teknologi- teknologi tersebut berupa komputer atau media elektronik lainnya seperti telepon seluler, jaringan internet, bahkan aplikasi media sosial. Generasi Z dibesarkan dengan web sosial, mereka berpusat pada digital dan teknologi adalah identitas mereka (Singh \& Dangmei, 2016). Lahir dan dibesarkan seiring dengan kemajuan-kemajuan dalam dunia 


\begin{tabular}{|c|c|c|c|c|}
\hline Share: Social Work Jurnal & VOLUME: 10 & NOMOR: 2 & HALAMAN: $199-208$ & $\begin{array}{c}\text { ISSN: 2339-0042 (p) } \\
\text { ISSN: 2528-1577 (e) } \\
\text { DOI: } 10.24198 / \text { share.v10i2.31443 }\end{array}$ \\
\hline
\end{tabular}

digital ini membuat Gen $Z$ berbeda dengan generasi sebelumnya. Perbedaan yang sangat mencolok dari generasi $Z$ dengan generasi lainnya ialah penggunaan telepon seluler.

Penggunaan akses internet dengan mudah melalui telepon seluler seiring hidup di era globalisasi pada Gen Z menghasilkan generasi yang dependen dengan internet. Dampak dari kemudahan dalam mengakses internet menciptakan internet sebagai sumber referensi utama dalam mencari suatu informasi. Seiring dengan peningkatan konektivitas global, pergeseran generasi dapat memainkan peran yang lebih penting dalam menentukan perilaku daripada perbedaan sosio-ekonomi. Kaum muda telah menjadi pengaruh yang kuat bagi orangorang dari segala usia dan pendapatan, serta pada cara orang-orang tersebut mengonsumsi dan berhubungan dengan mereka (Francis \& Hoefel, 2018). Penggunaan media sosial seperti Facebook, Twitter, Instagram, hingga TikTok dipenuhi oleh berbagai generasi. Jika Facebook lebih sering digunakan oleh Generasi $X$, maka TikTok lah yang didominasi oleh Generasi $Z$.

\section{TikTok, atau Douyin di China, adalah} layanan jejaring sosial berbagi yang menggunakan video berdurasi pendek sebagai media untuk menangkap dan menyajikan kreativitas, pengetahuan, dan momen lainnya yang dimiliki oleh ByteDance, sebuah perusahaan teknologi internet yang berbasis di Beijing dan diciptakan pada tahun 2012 oleh Zhang Yiming. Awal mula TikTok berawal dari tahun 2016 dengan nama Douyin dan baru berlayar di China hingga tahun 2017 diluncurkan dengan nama TikTok untuk seluruh dunia. Sebelum sepenuhnya beroperasi, TikTok bergabung dengan Musical.Iy, aplikasi lip sync, sebagai aplikasi seutuhnya. TikTok disukai oleh Gen Z karena karakteristik TikTok yang belum pernah dimiliki oleh media sosial lainnya. Seolah-olah dengan penggunaan TikTok, Gen Z dapat mengungkapkan identitas atau jati dirinya masing-masing.

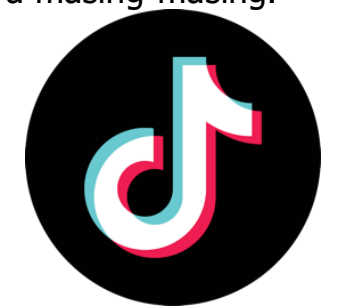

Gambar 1. Logo TikTok

Pemaparan teknologi sejak dini dan kemudahan dalam mendapatkan informasi merupakan sebuah perkembangan dalam membentuk Generasi Z. Media koran, radio, dan berita di televisi merupakan cara konvensional dalam memeroleh informasi. Adanya perkembangan internet yang menghasilkan media sosial membuat cara-cara konvensional tergeserkan dengan cara yang lebih mudah diakses yakni dengan menggunakan media sosial. Dengan kemudahan dengan mengunduh aplikasi, maka informasi yang ingin dicari menjadi mudah. Salah satu media sosial yang sedang hangat dibicarakan dan paling banyak digunakan oleh Gen Z adalah TikTok. Dengan menggunakan perspektif konstruksionis sosial dimana hasil interpretasi dari interaksi sosial membentuk sense of self kepada pengguna dan penonton yang tertarik pada konten tertentu di TikTok.

Mayoritas siswa percaya bahwa media sosial lebih banyak digunakan oleh para promotor suatu produk dibandingkan para pendidik, namun media sosial diikuti oleh penggunaan para pendidik dan siswa. Para responden pun setuju bahwa harus adanya perubahan dalam sistem akademik dan media sosial sebagai metode yang lebih inovatif dalam mencapai tujuan pendidikan (Kalia, 2013). Menurut Jayme (dikutip dalam Kalia, 2013), Jayme menyatakan bahwa jejaring media sosial dalam kalangan remaja merupakan bagian dari budaya mereka. Orang tua atau guru tidak dapat mengharapkan remaja meninggalkan Internet dan berkembang dalam masyarakat modern, karena komputer, teknologi, Internet, dan jaringan sosial digunakan dalam semua aspek kehidupan modern, bahkan di tempat kerja.

Perilaku Generasi Z dalam menggunakan TikTok sebagai media penyaluran edukasi dan aktivisme merupakan suatu perilaku manusia dalam periode umur remaja yang inovatif dan kreatif. Upaya intervensi dalam perilaku ini adalah mengubah cara pandang media sosial yang selalu di anggap negatif karena perilaku adikitif yang mampu dimunculkan oleh media sosial tersebut. Namun, kreativitas yang disajikan dalam TikTok oleh para pengguna merupakan salah satu cara yang dapat mengubah perspektif tersebut menjadi positif. Tujuan dari penulisan artikel yang disajikan ini adalah menginformasikan kepada para pembaca bahwa media sosial bukan sebagai media hiburan saja, tetapi mampu sebagai media edukasi dan aktivisme dalam dunia yang sudah terglobalisasi dari cara tradisional. Manfaat yang akan diperoleh dari bahan bacaan artikel adalah informasi baru yang didapatkan mampu mengubah perspektif suatu individu terhadap media sosial TikTok sebagai penyaluran edukasi 


\begin{tabular}{|c|c|c|c|c|}
\hline Share: Social Work Jurnal & VOLUME: 10 & NOMOR: 2 & HALAMAN: $199-208$ & $\begin{array}{c}\text { ISSN: 2339-0042 (p) } \\
\text { ISSN: 2528-1577 }(e) \\
\text { DOI: 10.24198/share.v10i2.31443 }\end{array}$ \\
\hline
\end{tabular}

maupun aktivisme. Adanya perspektif baru ini mampu mengubah individu untuk memiliki pemahaman lebih baik terhadap penggunaan TikTok karena adanya perkembangan diri dari hasil interpretasi interaksi sosial antar penonton dan pencipta konten.

\section{METODE}

Pendekatan yang akan digunakan dalam mengamati perilaku ini adalah penggunaan perspektif konstruksionis sosial dan teori interaksionisme simbolik dalam mendalami perilaku penggunaan TikTok terhadap Generasi Z. Pendekatan tersebut digunakan karena keinginan untuk mengetahui hasil yang diciptakan dari interaksi sosial antar pencipta konten dan penonton terhadap diri masing-masing dan cara pandang mereka terhadap dunia sosial melalui interaksi tidak langsung antar satu sama lain. Metode dalam penulisan artikel ini menggunakan studi kepustakaan. Proses dalam mencari referensi literatur untuk menulis artikel ini dengan cara mencari artikel atau jurnal resmi dari Google Scholar, Portal Garuda, Research Gate, Science Direct, Elsevier, dan bahkan rujukan elektronik lainnya seperti situs resmi TikTok. Pembatasan dalam pencarian pustaka difokuskan dengan mencari kata-kata kunci yang relevan dan paling sering muncul seperti media sosial dan Generasi Z.

\section{HASIL DAN PEMBAHASAN}

\section{Penggunaan Media Sosial dalam Bidang Edukasi}

Media sosial menggunakan teknologi seluler dan berbasis web untuk menciptakan platform yang sangat interaktif di mana individu dan komunitas mampu berbagi, membuat bersama, mendiskusikan, dan memodifikasi konten yang dibuat pengguna (Kietzmann, Hermkenz, McCarthy, \& Silvestre, 2011). Kegunaan TikTok sesuai dengan apa yang dijelaskan dikutipan diatas. Berbagai komunitas dengan minat yang berbeda ada didalamnya, entah itu komunitas masak, komunitas berbagi pengetahuan, hingga komunitas aktivisme. Penggunaan TikTok yang masif pada awal tahun 2020 dan ditambah dengan karantina COVID-19 pada pertengahan bulan Maret 2020, membuat TikTok menjadi aplikasi nomor satu yang paling banyak di download pada tahun 2020 (IDN Times, 2020). TikTok pun diprediksi akan meraih 1 miliar pengguna aktif di 2021 secara global. Perkembangan berbagai aplikasi seperti aplikasi jaringan sosial TikTok mampu membuat manusia atau individu mengonsumsi media sosial lebih banyak dari sebelumnya. Namun, apakah penggunaan jejaring sosial tersebut berdampak positif?.

Menurut Mao (2014) dalam menjelaskan bahwa penggunaan media sosial di bidang pendidikan yakni, penggunaan media sosial dalam bidang pendidikan oleh guru untuk pengajaran dan pembelajaran di kelas bersifat sporadis atau jarang, sementara penggunaan oleh siswa sendiri untuk tujuan pembelajaran tampaknya berlimpah tetapi juga insidental dan informal. Pencapaian dalam pengambilan ilmu pengetahuan mampu berasal dari mana saja. Entah itu pendidikan formal seperti Sekolah Menengah Pertama (SMP) atau Sekolah Menengah Atas (SMA) atau pendidikan informal seperti dari keluarga bahkan media sosial sekalipun. Sudah banyak diperdebatkan oleh para tenaga pendidik hingga peneliti, apakah media sosial mampu menjadi prasarana pendidikan formal maupun informal. Namun, fokus utama dalam artikel ini adalah tentang media sosial sebagai media edukasi dan aktivisme secara informal.

Di masa lalu, web adalah alat transfer informasi satu arah karena konten sebagian besar diproduksi oleh para ahlinya, yakni mereka yang menerbitkan informasi faktual dan memiliki keterampilan untuk membuat laman web. Itu merupakan definisi dari web 1.0 yang contohnya adalah situs berita "cnn.com". Pengguna hanya dapat melihat situs web tetapi tidak dapat memperbaiki, mengubah, atau menambahkan konten apa pun. Seiring teknologi berevolusi, web telah menjadi saluran universal yang interaktif dan partisipatif di mana pengguna diizinkan untuk menjadi produsen dan konsumen konten digital secara real time langsung melalui browser web. Contoh web yang sangat interaktif dan mampu diubah oleh pengguna ialah Wikipedia.

Penggunaan media sosial dalam bidang edukasi terjadi saat ini yakni saat pandemi COVID-19 yakni dimana pembelajaran tatap muka di pendidikan formal ataupun non formal mengalami perubahan untuk sementara waktu menjadi pembelajaran daring melalui program perangkat lunak videotelepon seperti Zoom dan Google Meet. Sebelum adanya perpindahan pembelajaran tatap muka ini, di lingkup pendidikan non formal yang berupa lembaga bimbingan belajar terdapat bimbingan belajar secara online. Contohnya adalah Zenius Education dan Ruang Guru. Keterbatasan beberapa murid dalam mengelola waktu antara sekolah dan 


\begin{tabular}{|c|c|c|c|c|}
\hline Share: Social Work Jurnal & VOLUME: 10 & NOMOR: 2 & HALAMAN: $199-208$ & $\begin{array}{c}\text { ISSN: 2339-0042 (p) } \\
\text { ISSN: 2528-1577 (e) } \\
\text { DOI: } 10.24198 / \text { share.v10i2.31443 }\end{array}$ \\
\hline
\end{tabular}

bimbingan belajar secara tatap muka membuat bimbingan belajar mendapatkan poin unggul yakni mampu dijadikan platform pembelajaran yang efektif walaupun secara online. Bimbingan belajar secara online seperti contoh di atas menggunakan tenaga pendidik yang unggul yakni dari beberapa lulusan universitas ternama dengan keunggulan diri tenaga pendidik masing-masing.

Penggunaan media sosial di lingkup pendidikan non formal sudah disebutkan di atas. Bagaimana dengan penggunaan media sosial di lingkup formal? Penggunaan media sosial dalam lingkup formal sebenarnya sudah sering dilakukan yakni dalam pencarian sumber daya pembelajaran yang tidak terbatas dari sumber yang berkredibilitas terpercaya. Pencarian yang tidak terbatas ini digunakan oleh siswa secara umum untuk melengkapi keperluan masing-masing siswa entah itu dalam melengkapi esai atau presentasi atau hanya sekedar pencarian suatu materi yang sebelumnya belum dipelajari di sekolah.Apabila penggunaan media sosial diberlakukan di dalam ruang kelas, guru perlu terus memantau siswa untuk mengetahui masalah apa pun yang dialami siswa tersebut. Memahami masalah, ketakutan, atau kebingungan siswa akan membantu fakultas lebih memahami kesulitan belajar siswa (Faizi, Afia, \& Chiheb, 2013). Contoh media sosial dalam bidang edukasi yang dicontohkan adalah Brainly. Brainly merupakan situs web belajar yang berbasis teknologi, dimana siswa menjadi seorang pengguna situs web menuliskan pertanyaan yang ingin mereka ketahui dan pengguna lainnya yakni siswa lain menjawab pertanyaan yang diajukan. Brainly merupakan situs web yang sangat interaktif karena dirangkai oleh pembuatnya dengan slogan untuk siswa, dari siswa.

Di dalam kelebihan pasti ada kekurangan. Setelah dijelaskan beberapa keuntungan dan contoh media sosial dalam bidang edukasi, berikut ini adalah contoh kekurangan dari penggunaan media sosial dalam bidang edukasi. Sebelumnya telah dijelaskan pentingnya monitor atau pengawasan oleh tenaga pendidik seperti guru terhadap siswa apabila penggunaan media sosial dibutuhkan. Keterbukaan hubungan komunikasi antar siswa dan guru pun harus dibentuk untuk meminimalisasi kejadian yang tidak menguntungkan bagi kedua belah pihak di masa depan. Media Sosial merupakan cara efektif untuk meningkatkan keterlibatan siswa. Karena fitur sosial dari sumber daya media sosial telah menarik perhatian jutaan orang di seluruh dunia, fitur yang sama ini juga mampu menarik perhatian siswa terhadap peluang belajar yang disediakan oleh institusi akademik mereka (Faizi, Afia, \& Chiheb, 2013). Komunikasi yang baik antar siswa dan guru mampu membuat siswa lebih aktif dalam berpartisipasi dalam kelas tatap muka. Menurut McLoughlin dan Lee (dalam Faizi, Aifa, \& Chiheb, 2013) menjelaskan bahwa Alat kolaboratif dan partisipatif seperti Wiki, blog, Google Docs dapat mendorong siswa untuk menjadi peserta aktif atau bahkan co-produser daripada konsumen pasif konten.

\section{Kemampuan TikTok Sebagai Platform Edukasi dan Aktivisme}

Menurut Zickhur (dalam Gruzd, Staves, dan Wilk 2012.) menjelaskan bahwa penggunaan media sosial seperti blog, wikis, dan situs jejaring sosial telah meningkat secara eksponensial, dan media semacam itu terus menjadi lebih terintegrasi ke dalam kehidupan kita sehari-hari. Contoh media sosial termasuk situs jejaring sosial (mis., Facebook); wiki (misalnya, ruang wik); layanan berbagi media (mis., YouTube); alat blogging (mis., Blogger); layanan mikro-blogging (mis., Twitter); bookmark sosial (mis., Lezat); alat manajemen bibliografi (misalnya, Zotero); dan alat berbagi presentasi (mis., Slideshare) (Gruzd, Staves, dan Wilk 2012). Teknologi yang sangat berkembang dan keperluan manusia yang semakin tinggi menyebabkan media sosial terus berkembang pula dengan permintaan yang ada. Hadirlah TikTok dengan keunikan dan karakteristiknya sendiri yakni, durasi videonya yang pendek, 15 atau 60 detik, yang mampu membuat pengguna mengakses aplikasi tersebut secara berulang-ulang karena durasi ini yang seolah-olah menghipnotis pengguna dengan kesenangan yang instan. Pembawaan TikTok yakni dengan iringan musik mampu membuat pengguna merasakan rasa senang yang bersifat adiktif dan menyebabkan pengguna terus menggulir konten-konten di dalam aplikasi tersebut.

Lalu, bagaimana cara pengguna mengakses genre konten tertentu yang ingin pengguna tonton atau ikuti? Cara kerja kontenkonten di TikTok berdasarkan algoritme. Menurut Kamus Besar Bahasa Indonesia (KBBI) online, algoritme adalah prosedur sistematis untuk memecahkan masalah matematis dalam langkahlangkah terbatas. Menurut Christensson (2013) dalam TechTerms.com, Algoritme adalah sekumpulan instruksi yang dirancang untuk melakukan tugas tertentu. Algoritme menjadi proses sederhana, seperti mengalikan dua angka, atau operasi yang kompleks, seperti memutar file 


\begin{tabular}{|c|c|c|c|c|}
\hline Share: Social Work Jurnal & VOLUME: 10 & NOMOR: 2 & HALAMAN: $199-208$ & $\begin{array}{c}\text { ISSN: 2339-0042 (p) } \\
\text { ISSN: 2528-1577 (e) } \\
\text { DOI: } 10.24198 / \text { share.v10i2.31443 }\end{array}$ \\
\hline
\end{tabular}

video terkompresi. Mesin pencari menggunakan algoritme kepemilikan untuk menampilkan hasil yang paling relevan dari indeks pencarian mereka untuk permintaan tertentu. Algoritme digunakan di seluruh aplikasi media sosial, namun algoritme TikTok berbeda karena penggunaan teknologi Artificial Intelligence (AI) nya yang mengatur jalannya algoritme TikTok dan algoritmenya yang bersifat lebih demokratis mampu membuat konten suatu pengguna menjadi viral. Pembuatan konten yang berupa video pun secara teknis sangat mudah. Pengguna dapat memilih musik dalam mesin pencari yang tersedia dalam fitur aplikasi dan bebas memilih sesuai keinginan pengguna. Pengguna pun dapat menyunting video mereka dengan gaya tulisan yang telah di sediakan dan penambahan efek video pun disediakan dalam fitur TikTok. Setelah merasa puas dengan konten video yang disunting, pengguna dapat menuliskan judul konten yang diinginkan dan dapat pula mencantumkan hashtag atau tagar. Menurut (Chang \& Iyer, 2012), Hashtag adalah tag metadata yang diawali dengan simbol hash, \#. Hashtag banyak digunakan pada layanan mikroblog dan berbagi foto seperti Twitter dan Instagram sebagai bentuk penandaan yang dibuat oleh pengguna yang memungkinkan referensi silang konten yang berbagi subjek atau tema. Contohnya, pencarian di Instagram untuk hashtag \#cats mengembalikan semua posting yang telah diberi tag dengan hashtag tersebut. Setelah simbol hash awal, hashtag dapat mencakup huruf, angka, dan garis bawah. Algoritme akan berjalan dengan sendirinya sesuai dengan apa yang pengguna cari, entah berasal dari hashtag atau sekedar menuliskan suatu kata kunci pada mesin pencarian.

Setelah penjelasan singkat tentang cara kerja aplikasi TikTok, bagaimana cara platform ini digunakan dalam bidang edukasi dan aktivisme? Edukasi dalam TikTok merupakan edukasi informal dimana ilmu-ilmu yang disajikan di dalam aplikasi ini bersifat umum ataupun spesifik tergantung konten apa yang disajikan oleh suatu pengguna. Salah satu contoh penyajian edukasi dan aktivisme dalam TikTok adalah dengan penggunaan hashtag untuk menjalani suatu kampanye. Dilansir dari Berita Lima, Beberapa waktu lalu lebih tepatnya pada bulan Oktober 2020, TikTok mengajak kreator untuk berbagi konten edukasi dalam kompetesi \#TikTokPintar. Kompetesi ini berhadiah ratusan juta rupiah dan para kreator dibebaskan untuk memberikan konten apapun namun dalam tema di bidang edukasi. Entah itu dapat berupa pengetahuan umum, bisnis, fakta umum, tips dan trik, bahasa asing, hingga IPTEK. Adanya Pandemi COVID 19 yang menyebabkan pelarangan keluar rumah kecuali untuk hal penting-penting saja, membuat TikTok banyak diunduh dan digunakan oleh Generasi Milenial dan Generasi Z. Menurut laporan artikel yang di lansir oleh Deloitte Global Millenial Survey 2020, bahwa hampir tiga perempat responden (27.528 responden, keduanya generasi milenial dan generasi $Z$, dari 43 negara) mengatakan pandemi telah membuat mereka lebih bersimpati terhadap kebutuhan orang lain dan bahwa mereka berniat mengambil tindakan untuk memberi dampak positif pada komunitas mereka. Hal ini dapat tercerminkan dari penggunaan tagar \#SamaSamaBelajar yang mendapatkan kurang lebih 20 juta tontonan oleh para pengguna. Survei tersebut juga mengungkapkan bahwa terlepas dari tantangan individu dan sumber kecemasan pribadi yang dihadapi generasi milenial dan Gen Z, mereka tetap fokus pada masalah sosial yang lebih besar, baik sebelum maupun setelah dimulainya pandemi. Jika ada, pandemi telah memperkuat keinginan mereka untuk membantu mendorong perubahan positif di komunitas mereka dan di seluruh dunia. Dan mereka terus mendorong dunia di mana bisnis dan pemerintah mencerminkan komitmen yang sama kepada masyarakat, menempatkan orang di atas keuntungan dan memprioritaskan kelestarian lingkungan.

Algoritme dan tagar memiliki peran vital dalam media sosial yang menggunakannya. Setelah membicarakan di bidang edukasi, bagaimana dalam bidang aktivisme? Sebelumnya telah dijelaskan di pendahuluan bahwa generasi yang paling banyak menggunakan TikTok adalah Generasi Z dalam rentang umur kelahiran tahun 1995-2010. Pengaruh Generasi Z saat ini sangat vital dikarenakan adanya globalisasi dan penggunaan teknologi yang masif. Ingat gerakan aktivisme Black Lives Matter dan protes kematian George Floyd pada bulan mei 2020? Ya, Tiktok berperan sangat penting dalam gerakan ini. Sebelumnya gerakan Black Lives Matter atau BLM bermula sejak tahun 2013 dengan penggunaan tagar \#BlackLivesMatter pertama kali di media sosial Facebook oleh Alicia Garza. Garza menuliskan kontennya di facebook pada tanggal 13 juli 2013 karena geram atas pembebasan George Zimmerman, seorang kulit putih, atas pembunuhan remaja kulit hitam yang tak bersenjata, Trayvon Martin. Dilansir dari National Geographic, Setahun kemudian, penembakan 


\begin{tabular}{|c|c|c|c|c|}
\hline Share: Social Work Jurnal & VOLUME: 10 & NOMOR: 2 & HALAMAN: $199-208$ & $\begin{array}{c}\text { ISSN: 2339-0042 (p) } \\
\text { ISSN: 2528-1577 }(e) \\
\text { DOI: 10.24198/share.v10i2.31443 }\end{array}$ \\
\hline
\end{tabular}

Michael Brown, remaja kulit hitam lainnya yang tidak bersenjata, oleh seorang polisi kulit putih di Ferguson, Missouri, mendorong Black Lives Matter untuk menjadi organisasi nasional. Lalu, dengan kematian George Floyd, protes Black Lives Matter telah meletus di seluruh dunia dan kata-kata itu sendiri dilukis dengan huruf kuning besar di jalan menuju Gedung Putih.



Gambar 2. Mural Black Lives Matter di Washington, DC.

Alicia Garza bersama kedua rekannya yakni wanita kulit hitam lainnya, Patrisse Cullors dan Opal Tometi membentuk organisasi Black Lives Matter Global Network Foundation, Inc. yakni sebuah organisasi global di AS, Inggris, dan Kanada, yang misinya adalah memberantas supremasi kulit putih dan membangun kekuatan lokal untuk campur tangan dalam kekerasan yang ditimbulkan pada komunitas Kulit Hitam oleh negara dan warga. Dilansir dari situs web Black Lives Matter, menjelaskan bahwa dengan memerangi dan melawan tindakan kekerasan ini, dapat menciptakan ruang untuk imajinasi dan inovasi kulit hitam, dan memusatkan kegembiraan kulit hitam, warga kulit hitam memenangkan peningkatan langsung dalam hidupnya.

Lalu apa yang dilakukan pengguna TikTok dalam gerakan aktivisme ini? Dilansir dari bbc.com, menjelaskan bahwa TikTok memiliki peran penting dalam Black Lives Matter, dengan mempopulerkannya sebagai tren di halaman Discover (halaman utama) dengan tagar yang disaksikan lebih dari 23 miliar kali. Salah satu konten video yang popular milik pengguna bernama Kareem Rahma dengan isi konten saat protes gerakan BLM di Minneapolis, daerah dimana Pembunuhan George Floyd oleh polisi bernama Derek Chauvin terjadi.

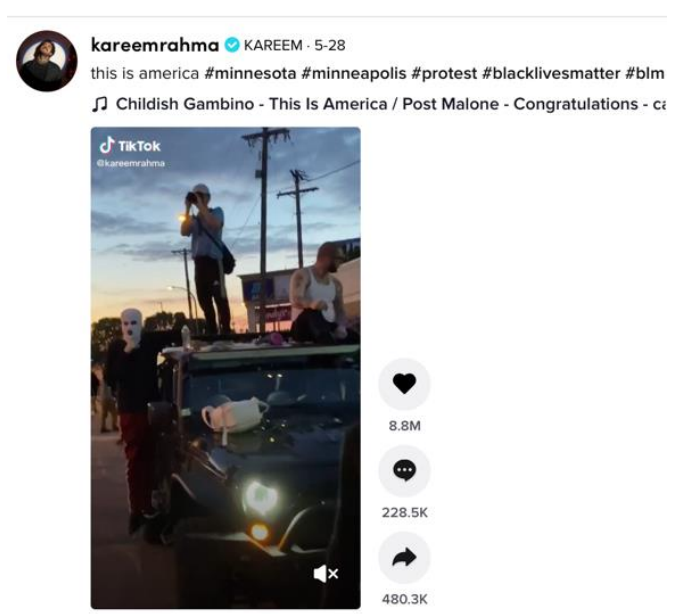

Gambar 3. Unggahan Video Pengguna TikTok Kareem Rahma

Unggahan video tersebut merupakan salah satu dari ribuan video lainnya dalam tagar \#blacklivesmatter di TikTok yang saat ini mencapai 23.8 miliar tontonan. Gerakan aktivisme yang terjadi di TikTok ini memunculkan perubahan yakni era baru aktivisme di dunia digital. Sebelumnya aktivisme di dunia digital sudah terjadi. Seperti di Twitter dengan penggunaan tagarnya untuk menginformasikan tentang suatu isu. Aktivisme digital dikuasai oleh Generasi Z karena dunia mereka yang sedari mereka lahir sudah terpapar oleh teknologi.

\section{\#blacklivesmatter \\ 23.8B views}

Gambar 4. Tagar BLM di TikTok

Di Indonesia sendiri, penggunaan aktivisme digital terjadi saat beberapa lalu yakni cuitan tagar di Twitter \#ReformasiDikorupsi. Dilansir dari Alinea.id, Generasi Z yang dikira apolitis akhirnya terlibat dalam aktivisme digital yang mengangkat isu korupsi, HAM dan isu sarat politik lainnya. Generasi Z bahkan memobilisasi massa untuk turun ke jalan dan melakukan aksi yang disebut-sebut sebagai aksi mahasiswa terbesar setelah Reformasi 1998. Hasilnya, pengesahan sejumlah rancangan undang-undang ditunda. Adanya pandemi COVID 19, keterlibatan Gen-Z dalam aktivisme digital semakin tampak. Kebijakan belajar dari rumah meningkatkan penggunaan internet dan memberikan banyak waktu untuk beraktivitas di media sosial. Hal itu 


\begin{tabular}{|c|c|c|c|c|}
\hline Share: Social Work Jurnal & VOLUME: 10 & NOMOR: 2 & HALAMAN: $199-208$ & $\begin{array}{c}\text { ISSN: 2339-0042 (p) } \\
\text { ISSN: 2528-1577 }(e) \\
\text { DOI: } 10.24198 / \text { share.v10i2.31443 }\end{array}$ \\
\hline
\end{tabular}

memperbesar kesempatan Generasi Z menjadi audiens atau bahkan partisipan sebuah aktivisme digital yang sedang berlangsung.

\section{Hubungan Perspektif Konstruksionis Sosial dan Teori Interaksionisme Simbolik dengan Hasil Studi}

Perspektif konstruksionis sosial berfokus pada bagaimana orang mengkonstruksi makna, $a$ sense of self, dan dunia sosial melalui interaksi mereka satu sama lain (Hutchinson, 2014). Dari perspektif konstruksionis sosial, berakarlah sebuah teori interaksionisme simbolik yang dimana teori ini mengusulkan bahwa saat manusia berinteraksi, mereka mengembangkan simbol yang mereka lampirkan makna. Kata-kata adalah simbol, begitu pula tindikan, tato, bendera nasional, dan gaya busana (Hutchinson, 2014). Dalam artikel ini, simbol yang dimaksudkan adalah TikTok dimana peran media sosial ini menjadi sarana orang-orang berinteraksi untuk tujuan yang sama yakni dalam pengumpulan ilmu baru dan melakukan gerakan sosial, berupa aktivisme.

Kunci dari hubungan antara perspektif dan teori ini dengan hasil studi adalah adanya interaksi sosial antar pengguna. Ada bukti yang menunjukkan bahwa interaksi sosial dengan orang lain yang dekat harus membawa manfaat terbesar (Sandstrom \& Dunn, 2014). Dalam penelitian dari (Wheeler, Reis, \& Nezlek, 1983), menunjukkan bahwa terlepas dari jenis kelamin mereka, orang- orang melaporkan bahwa mereka tidak terlalu kesepian ketika mereka memiliki interaksi yang lebih intim antar satu sama lain. Adanya nteraksi sosial ini membentuk sebuah makna dan dalam makna tersebut, bagaimana individu menerjemahkannya ke nilai-nilai yang mereka anut. Bagi para konstruksionis sosial, tidak ada realitas objektif tunggal, tidak ada realitas sejati yang ada "di luar sana" di dunia. Masing-masing individu memiliki realitas yang berbeda saat berinteraksi dalam konteks yang berbeda. Realitas dibentuk melalui interaksi sosial dan terus dibentuk kembali oleh interaksi sosial yang berkelanjutan (Hutchinson, 2014). Beberapa konstruksionis sosial fokus pada kesadaran individu, Mereka melihat diri berkembang dari interpretasi interaksi sosial. Dari adanya perkembangan diri tersebut hadirlah konsep looking glass self oleh Cooley yang diartikan secara singkat "I am what I think you think I am."

Penggunaan media sosial dalam bidang edukasi dan aktivisme oleh Generasi Z dilihat dari perspektif konstruksionis sosial dan teori interaksionisme simbolik adalah para pengguna saling bertukar makna terlepas dari perbedaan mereka karena mereka lebih mementingkan orang lain daripada dirinya. Namun, walaupun mereka lebih mementingkan kepentingan orang lain, mereka mendapatkan kebutuhan emosionalnya yakni dengan membantu sesama.

\section{Perbandingan Suatu Hasil Studi lain dengan Hasil Studi Ini}

Salah satu studi lain yakni di dalam bidang edukasi berjudul "Social media and education: reconceptualizing the boundaries of formal and informal learning" atau "Media sosial dan pendidikan: merekonseptualisasikan batasbatas pembelajaran formal dan informal" oleh (Greenhow \& Lewin, 2015). Dalam bagian ini penulis akan membandingkan hasil studinya dengan hasil studi oleh Greenhow dan Lewin. Hasil studi Greenhow dan Lewin menunjukkan bahwa untuk mengintegrasikan pembelajaran formal dan informal dalam penggunaan media sosial, dibutuhkan suatu model. Oleh sebab itu, Greenhow dan Lewin membuat model pembelajaran singkat menggunakan gagasan konstruktivis sosial dan konektivis beserta karya Colley, Hodkinson, dan Malcolm (2003) yang menyatakan bahwa siswa dapat mempraktikkan pembelajaran dengan atribut formal, informal, dan non-formal di berbagai konteks dan cukup banyak latihan. otoritas atas bagaimana mereka belajar, kapan mereka belajar, dan dengan siapa.

Model Greenhow dan Lewin merangkum atribut yang diajukan oleh Colley, Hodkinson, dan Malcolm (2003), mengenali masalah yang timbul dalam mereduksi konsep kompleks menjadi serangkaian label. Misalnya, atribut seperti itu dapat diganggu gugat, diinterpretasikan secara berbeda, dan mungkin tidak sama pentingnya dalam konteks pembelajaran yang berbeda (Colley, Hodkinson, dan Malcolm 2003). Selain itu, 'beberapa dari "kutub yang berlawanan" mungkin benar-benar hidup berdampingan' (Colley, Hodkinson, dan Malcolm 2003). (Greenhow \& Lewin, 2015) menjelaskan bahwa mereka telah mengembangkan atribut lebih lanjut dengan mempertimbangkan atribut pembelajaran apa yang mungkin spesifik untuk konteks media sosial. Model yang ditunjukkanpun dimaksudkan untuk menawarkan titik awal untuk diskusi daripada menjadi solusi yang telah ditentukan sebelumnya untuk masalah pemahaman kompleksitas pembelajaran. Dalam karya ini telah memungkinkan Greenhow dan Lewin untuk 


\begin{tabular}{|c|c|c|c|c|}
\hline Share: Social Work Jurnal & VOLUME: 10 & NOMOR: 2 & HALAMAN: $199-208$ & $\begin{array}{c}\text { ISSN: 2339-0042 (p) } \\
\text { ISSN: 2528-1577 }(e) \\
\text { DOI: 10.24198/share.v10i2.31443 }\end{array}$ \\
\hline
\end{tabular}

mengusik dan mempermasalahkan dampak media sosial dalam konteks pendidikan.

Model yang dibuat oleh Greenhow dan Lewin diilustrasikan ke dalam penelitian di studi Eropa dan studi Amerika Serikat. Studi Eropa sepenuhnya berfokus pada penanaman media sosial di ruang kelas sekolah. Aktivitas dipimpin oleh guru kelas daripada minat siswa dalam penggunaan sosial media dalam kelas. Dapat dilihat bahwa ini merupakan pembelajaran secara formal. Sedangkan Studi AS menggambarkan bahwa komunitas yang dimulai dan dilihat oleh 'pakar', tetapi konten, tujuan, dan tindakannya sebagian besar didorong oleh kontribusi dari anggota jaringan. Studi AS dapat di ilustrasikan sebagai pembelajaran informal. Dalam kedua kasus tersebut, media sosial menawarkan peluang bagi kaum muda untuk memanfaatkan kekuatan jaringan dan mencari keahlian yang relevan. Namun, penerapan penggunaan media sosial saja yang berbeda.

Jika di perbandingkan hasil studi ini dengan hasil studi penulis maka hasilnya adalah konsisten dan mendukung. Greenhow dan Lewin menulis tentang model yang mampu di diskusikan lebih lanjut dalam penggunaan media sosial di dalam pembelajaran formal dan informal. Apabila model Greenhow dan Lewin dikembangkan dan di diskusikan lebih lanjut, maka model yang dibuat ke depannya mampu menyokong pembelajaran informal seperti yang artikel ini tuliskan, yakni penggunaan TikTok dalam bidang edukasi maupun aktivisme.

Implikasi dari hasil studi ini digunakan untuk para pembaca yang ingin mengetahui apakah penggunaan media sosial berupa TikTok oleh Generasi Z mampu digunakan sebagai media positif yakni sebagai media edukasi dan aktivisme. Manfaat penggunaan TikTok sebagai media edukasi dan aktivisme merupakan manfaat yang bagus dalam upaya mencari ilmu baru dan hal baru. Dikarenakan TikTok merupakan salah satu aplikasi yang mempu mengubah cara permainan media sosial sebelumnya dengan keunikan mereka yakni video berdurasi 15-60. Maka tidak heran dampaknya terhadap banyak sektor di dunia.

\section{SIMPULAN DAN SARAN}

Kesimpulan dari artikel ini melalui studi pustaka adalah penggunaan media sosial di bidang pendidikan memang menguntungkan, namun perlu lebih banyak penelitian dan model lebih lanjut untuk penerapannya dalam kegiatannya. Penggunaan media sosial tidak selalu buruk atau bersifat negatif. Apabila memiliki tujuan positif seperti melakukan aktivisme dengan cara menyebarluaskan informasi atau mengumpulkan ilmu baru yang bersifat sengaja maupun tidak disengaja.

Hasil studi ini menyatakan bahwa penggunaan sosial media TikTok oleh Generasi Z mampu mengembangkan suatu makna dan sense of self akibat dari interaksi sosial yang konstan sesama pengguna. Dengan adanya interaksi sosial, masing-masing pengguna akan menerjemahkannya sesuai dengan nilai-nilai yang mereka anut, lalu dari adanya pertukaran perspektif tersebut muncullah berbagai realitas dalam hidupnya. Karena masing-masing pengguna atau individu merupakan makhluk yang unik.

Saran penulis dalam penulisan artikel ini adalah pengembangan media sosial dalam bidang pendidikan maupun gerakan sosial sudah cukup luas dan baik untuk digunakan. Namun, apabila ada pengembangan dalam model yang bersifat sistematik dan mampu diaplikasikan secara utuh, maka akan lebih baik hasilnya bagi individu maupun komunitas.

\section{UCAPAN TERIMA KASIH}

Penulis ingin mengucapkan puji syukur kepada Allah SWT karena berkat rahmat-Nya penulis mampu menyelesaikan artikel ini. Penulis pun berterima kasih kepada dirinya sendiri karena kuat bertahan dalam menyusun serta menulis artikel ini dengan jerih payahnya. Terima kasih juga ditujukan untuk Bu Nurliana Cipta Apsari, Bu Hetty Krisnani, dan Bu Binahayati selaku dosen mata kuliah Human Behavior and Social Environment. Ucapan terima kasih juga penulis ucapkan kepada orang tua penulis karena mereka penulis mampu menulis artikel ini. Penulis juga ingin berterima kasih kepada teman-teman Kesejahteraan Sosial 2019 yakni Erika Putri, Nabila Nurul A., dan Farrelia Azzahra yang telah membantu penulis dalam menilik saran dan nasihat kepada penulis selama menyusun artikel ini.

\section{DAFTAR PUSTAKA}

Algoritme (Def.1) (n.d). Dalam Kamus Besar Bahasa Indonesia (KBBI) Online. Diakses Melalui https://kbbi.kemdikbud.go.id/entri/algorit me , 28 Desember 2020. 


\begin{tabular}{|c|c|c|c|c|}
\hline Share: Social Work Jurnal & VOLUME: 10 & NOMOR: 2 & HALAMAN: $199-208$ & $\begin{array}{c}\text { ISSN: 2339-0042 (p) } \\
\text { ISSN: 2528-1577 (e) } \\
\text { DOI: 10.24198/share.v10i2.31443 }\end{array}$ \\
\hline
\end{tabular}

Berita Lima. (2020, Oktober 7). TikTok Ajak Kreator Berbagi Konten Edukasi dalam Kompetisi \#TikTokPintar. Retrieved from Berita Lima: https://beritalima.com/tiktokajak-kreator-berbagi-konten-edukasidalam-kompetisi-tiktokpintar/

Black Lives Matter. (n.d.). About. Retrieved December 2020, from Black Lives Matter: https://blacklivesmatter.com/about/

Brainly. (2020). About Brainly. Retrieved from Brainly: https://brainly.com/careers/about.html

Byte Dance. (2012). Our Products. Retrieved from ByteDance: https://www.bytedance.com/en/products

Chang, H.-C., \& Iyer, H. (2012). Trends in Twitter Hashtag Applications: Design Features for Value-Added Dimensions to Future Library Catalogues. Library Trends, 61(1), 248258.

Christensson. (2013, August 2). Algorithm Definition. Retrieved December 2020, from TechTerms: https://techterms.com/definition/algorith $\mathrm{m}$

Colley, H., P. Hodkinson, and J. Malcolm. 2003. Informality and Formality in Learning: A Report for the Learning and Skills Research Centre. London: LSRC

Deloitte Global. (2020). Deloitte. Retrieved from The Deloitte Global Millennial Survey 2020 Millennials and Gen Zs hold the key to creating a "better normal": https://www2.deloitte.com/global/en/pag es/aboutdeloitte/articles/millennialsurvey.html\#

Faizi, R., Afia, A. E., \& Chiheb, R. (2013). Exploring the Potential Benefits of Using Social Media in Education . International Journal of Engineering Pedagogy, 50-53.

Francis, T., \& Hoefel, F. (2018, November 12). 'True Gen': Generation $Z$ and its implications for companies. Retrieved from McKinsey \& Company: https://www.mckinsey.com/industries/con sumer-packaged-goods/our-insights/truegen-generation-z-and-its-implications-forcompanies

Galer, S. S. (2020, Desember 23). Bagaimana TikTok mengubah dunia di 2020. Retrieved from BBC: https://www.bbc.com/indonesia/vert-cul55421498

Greenhow, C., \& Lewin, C. (2015). Social media and education: reconceptualizing the boundaries of formal and informal learning. Learning, Media and Technology, 1-25.

Gruzd, A., Staves, K., \& Wilk, A. (2012). Connected scholars: Examining the role of social media in research practices of faculty using the UTAUT model. Computers in Human Behavior, 23402350.

Hartigan, R. (2020, July 8). She co-founded Black Lives Matter. Here's why she's so hopeful for the future. Retrieved December 2020, from National Geographic: https://www.nationalgeographic.com/hist ory/2020/07/alicia-garza-co-foundedblack-lives-matter-why-future-hopeful/

Hutchinson, E. D. (2014). Dimensions of Human Behavior: Person and Environment. Richmond, Virginia, USA: SAGE Publications.

IDN Times. (2020, Desember 17). 10 Aplikasi Paling Banyak Diunduh pada 2020, Siapa Nomor 1? Retrieved from IDN Times: https://www.idntimes.com/tech/trend/izz a-namira-1/10-aplikasi-paling-banyakdiunduh-pada-2020-siapa-nomor/10

Kalia, G. (2013). A Research Paper on Social media: An Innovative Educational Tool. Issues and Ideas in Education, 43-50.

Kementrian Pendidikan dan Kebudayaan Republik Indonesia. (n.d.). Definisi Algoritme. Retrieved December 2020, from Kamus Besar Bahasa Indonesia (KBBI) Online: https://kbbi.kemdikbud.go.id/entri/algorit me

Kietzmann, J. H., Hermkenz, K., McCarthy, I. P., \& Silvestre, B. S. (2011). Social media? Get serious! Understanding the functional building blocks of social media. Business Horizons, 241-251.

Malloy, D. (2020, July 26 ). Ozy. Retrieved from THE POWER OF TIKTOK: https://www.ozy.com/news-andpolitics/the-power-of-tiktok/362145/

Mao, J. (2014). Social media for learning: A mixed methods study on high school students' technology affordances and perspectives. Computers in Human Behavior, 213-223.

Sandstrom, G. M., \& Dunn, E. W. (2014). Social Interactions and Well-Being: The Surprising Power of Weak Ties. Personality and Social Psychology Bulletin, 40(7), 910-922.

Singh, D. A., \& Dangmei, J. (2016). UNDERSTANDING THE GENERATION Z: 


\begin{tabular}{|c|c|c|c|c|}
\hline Share: Social Work Jurnal & VOLUME: 10 & NOMOR: 2 & HALAMAN: $199-208$ & $\begin{array}{c}\text { ISSN: 2339-0042 (p) } \\
\text { ISSN: 2528-1577 }(e) \\
\text { DOI: } 10.24198 / \text { share.v10i2.31443 }\end{array}$ \\
\hline
\end{tabular}

THE FUTURE WORKFORCE . South Asian Journal of Multidisciplinary Studies (SAJMS), 1-5.

Warda, Y. S. (2020, Juni 29). Gen-Z dan aktivisme digital. Retrieved from Alinea:

https://www.alinea.id/kolom/gen-z-danaktivisme-digital-b1ZOR9vuZ
Wheeler, L., Reis, H., \& Nezlek, J. (1983). Loneliness, Social Interaction, and Sex Roles. Journal of Personality and Social Psychology, 45(4), 943-953. 